\title{
AT-THOYYIB SHOP INVENTORY MANAGEMENT SYSTEM
}

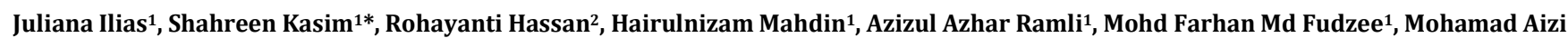 \\ Salamat ${ }^{1}$
}

\section{${ }^{1}$ Faculty of Computer Science and Information Technology, Universiti Tun Hussein Onn Malaysia, Johor, Malaysia ${ }^{2}$ Faculty of Computing, Universiti Teknologi Malaysia, Skudai, Johor, Malaysia}

\section{*Corresponding author: shahreen@uthm.edu.my}

This is an open access article distributed under the Creative Commons Attribution License, which permits unrestricted use, distribution, and reproduction in any medium, provided the original work is properly cited

\section{ARTICLE DETAILS}

\section{Article History:}

Received 12 November 2017 Accepted 12 December 2017 Available online 1 January 2018

\section{ABSTRACT}

At-Thoyyib Inventory Management System is developed as an online system to facilitate inventory management that includes the entry and exit of goods in storage. The main purpose of this system development is to assist a inventory management for At-Thoyyib Shop that will be managed systematically and efficiently. From observations and interviews that have been made, the problem that has identified is, the system used in the At-Thoyyib Shop is managed manually. For example, if the inventory data were recorded using book, there are a few disadvantages that were, books is perishable, and a person can also make errors in recording the data in the book. The objective of this system is to develop a report module for data in and out of inventory and also to facilitate access of the information goods. The methodology that has been used in this developing system is waterfall model. The advantages of waterfall model are that it is easy to explain to users. Structural approach for this model of the activities of each stage and well defined. In addition, it also helps to plan and schedule a project. In conclusion, the inventory management system is developed to expedite the process of recording inventory information and improve the efficiency and accuracy to generate reports required by management.

\section{KEYWORDS}

Inventory management, waterfall model, recorded, At-Thoyyib Shop.

\section{INTRODUCTION}

Soft Good management within an organization is important for determining the profitability and development of the enterprise. Business involving a lot of inventory is vital in having good management [1] Inventories or stocks played a role in a business. This is due to its position as the most important asset is the heart and life of the continuity of operations. Some organizations have a problem with the question of inventory. Often occurring complications and it involves a human error in registering an information. Inventory management is a very interest should and must be done carefully to ensure that no waste either in the form of revolving capital or public premises.

From observations and studies have been made, found a small business shops At-Thoyyib in Parit Raja still use manual inventory management system [2]. Store At-Thoyyib is selling groceries, namely frozen goods such as chicken samosa, spring rolls, samosa fish by fish, and some other frozen goods, and household items. There is also an organic-based drug sold here. This store involves extensive inventory and is in dire need of a good inventory management system to run their business efficiently and orderly manner. To produce a systematic inventory management system for At-Thoyyib in managing recorded data in and out of inventory for the stores [3]. Through observation and some research done, there are some problems that have been identified. From problems identified system used in this store are handled manually, recorder, can also make mistakes in registering data in the book and reporting for inventories done manually and no distribution types goods.

\subsection{Objective}

Inventory management system for AT-Thoyyib was developed is intended to develop an online system that can help the store inventory management for managed systematically and efficiently. Among the objectives of the development of this system are:

1. Inventory management system for AT-Thoyyib in recorded data inventory in the shops.

2. Develop a report module for data in and out of inventory data and facilitating access to information goods.

\subsection{Project Scope}

This system will be used by employees and supervisors at At-Thoyyib Store, Parit Raja responsible for the inventory management work at the store. The inventory data used in this system obtained from the AtThoyyib Store itself. At-thoyyib shop is a grocery store selling wet and dry goods. Wet items consist of, chicken samosas, vegetable samosas, sardines and roti canai. Dry items are like household items such as dishwashers, detergents and other household needs [4]. The system also has several modules designed in this system which is the login module before the user uses this inventory management system, he needs to go through the previous login by entering the id and password number.

The Inventory Module serves as a module for displaying items related information. Items will be classified according to their respective categories like frozen, dry goods, medicines and several other categories. The Search module allows users to search for items and suppliers by entering keywords before searching. The Supplier Module works to see a list of suppliers that supply goods to the store. Additionally, users can also add a supplier's name to add a new provider [5]. The Payment module works to record outgoing items, and this will be connected to the 
inventory module. If there are customers who buy the goods, the sales module will record the type of goods, quantities, and prices and on the inventory module, the quantity of the item is updated automatically. The Damaged Goods Module works to record items in case of damage. The Reporting module works to generate reports of activities that have been conducted which record the information of incoming goods, supplier information, damaged goods information as well as daily income financial reporting.

\section{LITERATURE REVIEW}

\subsection{Introduction}

This chapter describes about studies that have been made to the existing system and the system will be developed. Literature review is intended to gather information and identify problems that occur in search of opportunities in order to improve the productivity of the system that had been reviewed [6]. A researcher explaining that the literature review involved conclusions writing of articles in journals, books and other documents that explain the past and current condition information, organize a literature in a particular topic and documenting the need for the proposed study [1]. This chapter is a method for identifying problems and deficiencies found in the existing system. This allows system developers can add as well as improving the current system deficiencies. This literature review is important for information and facts related to a project that will be developed later. This helps system developers to produce a system that is useful and better than existing systems.

\subsection{Equivalent System Review}

Study on the equivalent system or a system that already is very important to develop a system. It is intended as a reference and guide for the development of this system. In addition, the review of the system could also provide developers the equivalent system with related information is very useful while developing the system in error not occurred. Next, through this study trading system developer can find out shortcomings and advantages of existing systems. With this, a trading system developer can see in detail how to develop a better system than the current system, namely by improving deficiencies and innovate of the systems to be developed [7-9]. Systems studied have some similarities that can be used as a reference and is associated with the system will be developed.

\subsubsection{System Inventory information system Unit Integrated UiTM Terengganu}

This page was developed to store information inventory of computer equipment and other equipment placed in the custody of integrated information system Unit, UiTM Terengganu.

\subsubsection{Application system Inventory Small Medium}

Application system of medium-Small Inventory is one system developed by student Project Bachelor of Faculty of computer science and information technology, Universiti Tun Hussein Onn Malaysia in 2011. The system developed is intended to help the company Mi \& Da Enterprise operating in Tongkang Pechah, Batu Pahat which have problems in the management system of the company. This system used the programming language Visual Basic 2008 Express Edition. In this system there are some modules which module suppliers, incoming and outgoing goods module, and module search. Module information records has information about goods, staff and suppliers.

\subsection{Comparison of Equivalent System}

Every explanation of both the system already described, there are several advantages and disadvantages that have been identified. Similarities and differences by existing systems and systems to be developed will more clearly see, by scheduling each of the similarities and differences.

Table 1: Comparison of equivalent system.

\begin{tabular}{|l|c|c|c|}
\hline \multicolumn{1}{|c|}{ The Function of System } & $\begin{array}{c}\text { Inventory system, Units System } \\
\text { Information, Integrated Uitm } \\
\text { Terengganu }\end{array}$ & $\begin{array}{c}\text { System Applications Industry, } \\
\text { Inventory Small Medium the for } \\
\text { company MI \& Da Enterprise }\end{array}$ & $\begin{array}{c}\text { Management system Store } \\
\text { Inventory At-Toyyib }\end{array}$ \\
\hline Module Log come in & There is a & There is a & There is a \\
\hline Module Registeration New Users & There is a & There is a & There is a \\
\hline Module Entry New Goods & There are no & There is a & There is a \\
\hline Module update Goods out come in & There is a & There are no & There is a \\
\hline Module Payment & There are no & There are no & There is a \\
\hline Module Goods Damaged & There are no & There are no & There is a \\
\hline $\begin{array}{l}\text { Add/Delete users and Information } \\
\text { Inventory }\end{array}$ & There is a & There is a & There is a \\
\hline The Search Module & There is a & There is a \\
\hline Generate Report & There are no & There is a \\
\hline
\end{tabular}

The result of the comparison was made against equivalent systems in Table 1, found there are some similarities and differences between those systems. To make this comparison, it can be used as a guide to develop a better system.

\section{METHODOLOGY}

\subsection{Introduction}

Methodology is important for guiding the researchers how data collected and collected. Explanation of the methodology used will facilitate researchers in conducting research in a more systematic and save time. The methodology has guidelines that contain models and specific techniques to be followed in implementing each activity in the system development life cycle. The use of the methodology in the development of the system will increase the productivity and quality of a system to be developed. System development lifecycle (SDLC) is a traditional methods and methodology for the development of a system and it's use in the development of this system. SDLC is a phased approach in analysis and system design that says that a system is well developed through the use of life cycle user activity and specific system analyst.

\subsection{Waterfall Methodology}

Therefore, the model selected for development of this project was the waterfall Model. The waterfall model is a sequential flow linear. Where any progress is seen as flowing steadily downwards (like a waterfall) through the phases of implementation of the software. This means that any phase in the development process starts only if the previous phases are finished and complete. Waterfall approach does not allow the process to go back to the previous phase to handle any changes in requirements.

The benefit of this waterfall model is that it's simple to explain to users. Approach, this model structure for each level and developed further defined in well. Besides that it also helps to plan and schedule a of the project. In the model this waterfall has five phases, requirements phase, design phase, implementation phase testing and last but not least is the maintenance phase. Description and diagrams of the waterfall model is shown in Figure 1 and will be described in the next section. There are five phases in the model this waterfall, which is planning phase, phase analysis, design phase, implementation phase and also the testing phase. Each phase will be explained in the next section.

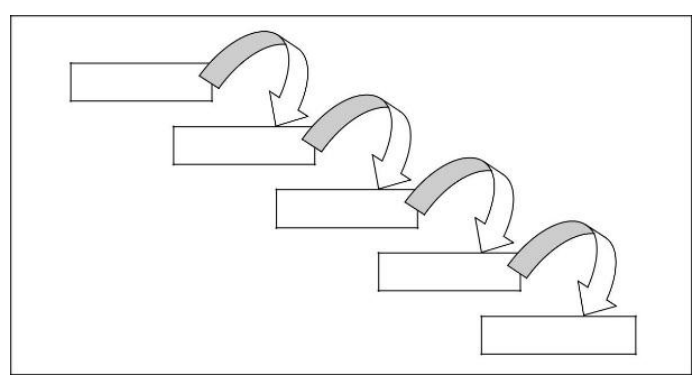

Figure 1: Waterfall Model 
There are five phases involved during the implementation of the system. The work describes the workflow for each phase in the development methodology. Each phase has tasks that are carried out as well as outputs, namely as a result of the task.

Table 2: Shows the workflow of each phase.

\begin{tabular}{|c|l|l|}
\hline Phase & \multicolumn{1}{|c|}{ Task } & \multicolumn{1}{c|}{ The output of the } \\
\hline Planning & $\bullet$ Gantt Chart & $\begin{array}{l}\bullet \text { Report the proposed that is contains the chapter 1 to say } \\
\text { Introduction }\end{array}$ \\
\hline Analysis & $\bullet \begin{array}{l}\text { Interview } \\
\text { Report the proposed that is contains the Chapter 2 to say } \\
\text { literature review }\end{array}$ \\
\hline Design & $\bullet \begin{array}{l}\text { Design data backup } \\
\text { Design flow chart } \\
\text { Design 2006 4 and DFD }\end{array}$ & $\begin{array}{l}\text { Flow chart, DFD and 2006 } \\
\text { Machine Interface }\end{array}$ \\
\hline The implementation of the & $\bullet$ Implement a system dicadangkan & $\bullet$ Prototype system \\
\hline Testing & $\bullet$ User Testing & $\begin{array}{l}\bullet \text { To ensure that the system output and error free required } \\
\text { to go out after inputs included. }\end{array}$ \\
\hline
\end{tabular}

\subsection{Development Planning}

Development planning is divided into two, namely the development phase 1 and phase 2 development. Table 3 shows the development phase 1 and Table 4 shows the development phase 2 .

Table 3: Development Phase 1

\begin{tabular}{|l|l|l|}
\hline \multicolumn{1}{|c|}{ Phase } & \multicolumn{1}{|c|}{ Input } & \multicolumn{1}{c|}{ As a result, } \\
\hline Introduction & $\begin{array}{l}\text { Make the interview to } \\
\text { identify problems and } \\
\text { desired objectives. }\end{array}$ & $\begin{array}{l}\text { The goal, problem, } \\
\text { objectives, scope }\end{array}$ \\
\hline Literature Review & $\begin{array}{l}\text { Make observations with } \\
\text { comparing system ready } \\
\text { there is }\end{array}$ & $\begin{array}{l}\text { Got it ensure system to } \\
\text { be developed there lack } \\
\text { of. }\end{array}$ \\
\hline Methodology & $\begin{array}{l}\text { Choose model waterfall the } \\
\text { life as cyclic of the } \\
\text { development of the } \\
\text { system. }\end{array}$ & $\begin{array}{l}\text { Apply the water model } \\
\text { waterfall into the } \\
\text { planning the system. }\end{array}$ \\
\hline Analysis and Design & Design architecture & Memodelkan mode \\
\hline
\end{tabular}

Table 4: Development phase 2

\begin{tabular}{|l|l|l|}
\hline \multicolumn{1}{|c|}{ Phase } & \multicolumn{1}{|c|}{ Input } & \multicolumn{1}{c|}{ As a result, } \\
\hline $\begin{array}{l}\text { The implementation } \\
\text { of the }\end{array}$ & $\begin{array}{l}\text { Developing system } \\
\text { According to the required }\end{array}$ & Prototype system \\
\hline \multirow{3}{*}{ Testing } & $\begin{array}{l}\text { Testing carried out on } \\
\text { program codes and } \\
\text { systems also the interface } \\
\text { system }\end{array}$ & $\begin{array}{l}\text { Non-Generated System } \\
\text { the error and Output } \\
\text { required to go out after } \\
\text { inputs included. }\end{array}$ \\
\hline
\end{tabular}

\section{ANALYSIS AND DESIGN}

\subsection{Introduction}

Phase analysis and design is a second and third phase after phase of planning. The process of analysing the needs and the process of designing a page between phases of work that need to be addressed before a system through a process of development that actually. This chapter describes system design that will illustrate, and travel system developed. Design of a system that has been stated in the previous chapter is divided into two parts, namely, database design, and application of the system. The design database is represented through a Data Flow Diagram (DFD) and Entity Relationship Diagrams (2006 4) built was used as a model in developing a database for this system. Among the elements that are involved in this chapter is the entity Relationship Diagram (2006 4), Data Flow Diagrams (DFD), flow charts and Data Dictionary. The implementation of this chapter is very important it is to ensure that the system will be developed meets the needs of users and achieve the objectives that have been set

\subsection{System Requirement Analysis}

Needs analysis system is a task analysis of the systems developed to get a thorough understanding of the system to the environment. System requirements analysis process is divided into two, namely, Flowchart, DFD and 20064.

Flow chart is an elaboration on steps to be taken to complete a task, using certain symbols. It can also be defined as the graph consisting of geometric forms that are connected by the flow. Flow chart has several symbols that represent specific functions, with this flow chart, travel or flow of a system that can be seen more clearly.

Figure 2 shows the employee flow chart for Store Inventory management system At-Thoyyib. Flow system begins with employees entering id and password. Once the password is verified correct, then the employee will be able to see the main page of the system. Between the modules contained within the main page is information providers, information goods, goods in, goods damaged, sales of goods, update employees and leave application. Module suppliers, employees can add new and update information on new suppliers. Module information goods, employees can add and update new items into the system. Employees can also add goods in. While at damaged goods module and module sales of goods, it serves as the goods out. Once done using the employee will need to logout to ensure that id employees are not used by other employees. Figure 3 shows the flow chart for inventory management System Administrator Store AtThoyyib

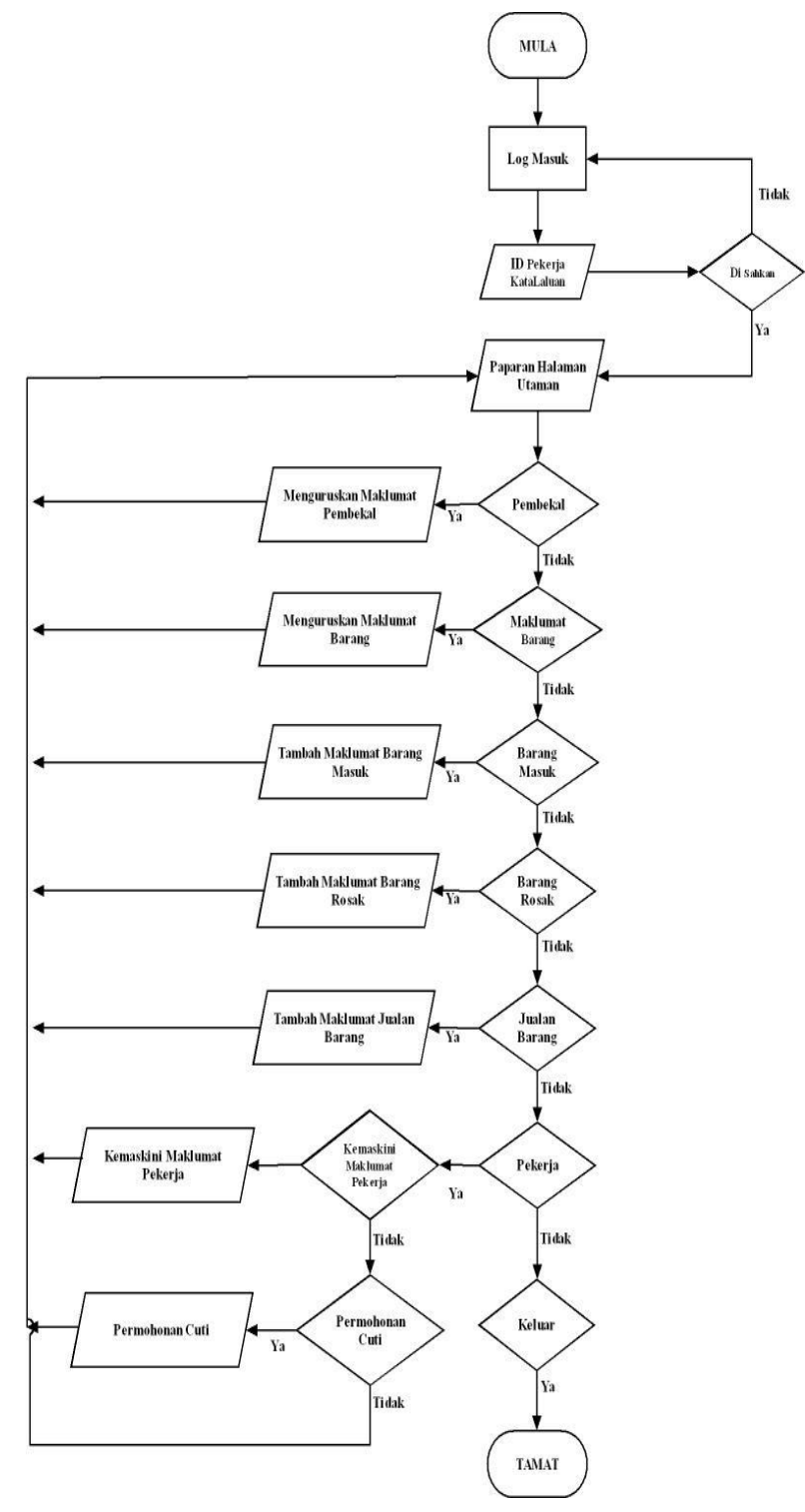

Figure 2: Employee flow chart 


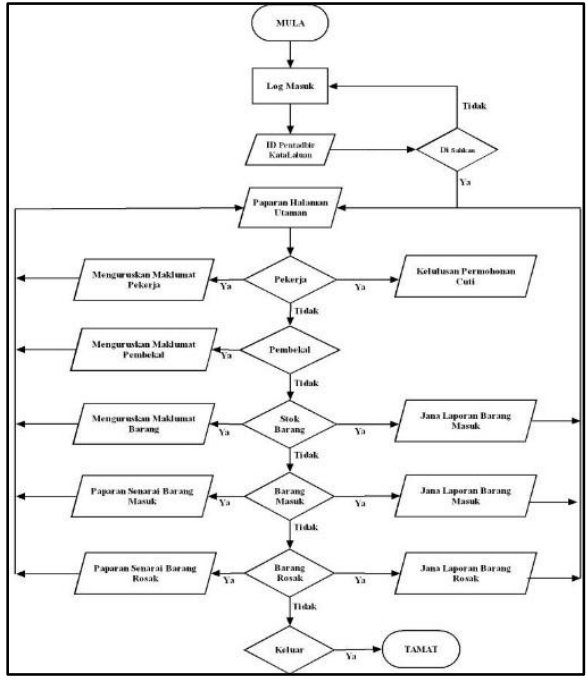

Figure 3: Administrator flowchart

DFD shows the course of an System. From Data Flow Diagram (DFD) can also be understood how the system works and as a reference in designing database system. Figure 4 shows the diagram context for the system to be developed.

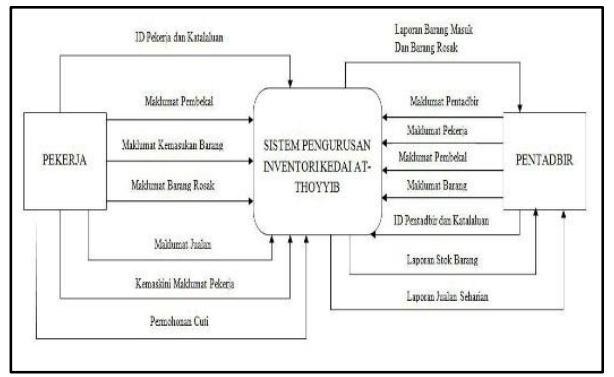

Figure 4: Context Diagram

Figure 5 shows the zero-level data flow diagram for Inventory Management Systems Store At-Thoyyib. The figure depicts the entire process happens in the system. There are four processes that are in the system process for log on, update information, generate reports and search. Logon process used by employees and administrators by entering the number of employees and the correct password. The next process employees can update information items, suppliers, damaged goods, goods-in and sale transactions.

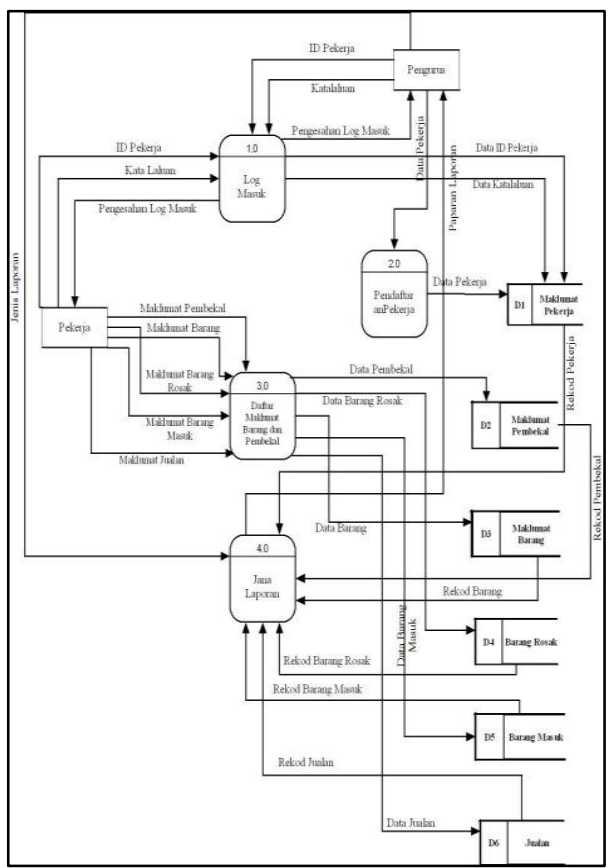

\section{IMPLEMENTATION AND TESTING}

\subsection{Introduction}

Implementation and testing phase is the final phase which was implemented in the development planning system. This phase is an important phase in the implementation of a development of the system. This phase is intended to ensure the development of the prototype can be conducted in a structured manner and produce output that are expected by the user.

This phase is carried out starting from the development phase to the completion of the system developed. Test made on a system is intended to determine whether a system has been developed to achieve the objective and the objective which has been set on the current chapters develop the system. In addition, testing is done on the system that is developed in order to identify weaknesses in the systems developed for finding a solution to overcome the weaknesses as well as improving.

\subsection{Implementation}

Implementation refers to the process of coding the design phase of the program. In the process, the language used is PHP and MySql were used as a medium for translating user requirements to the function system. In this phase, some modules of the system have been developed to meet the function of the system. There are several modules in the system, including module supplier, a module of goods, goods in and damaged, sales, employee module, a module leave application, approval module and leave the module report.

\subsection{System Testing}

In the development of inventory management System At-Shop, Thoyyib testing phase is divided into two parts the first testing of the functionality of the system and Alpha testing. The testing was done to review the level of their capabilities and effectiveness of the system to the environment of the user.

\subsection{Module Function}

Figure 6 shows the main page of the system developed. Interface home page is also the interface page to log on to the system. On this page there is a login for employees and administrators. Through this view the user will be asked to enter number of valid id and password. Event id or password has been entered incorrectly, an error messagewill be issued directing the user to fill in the required information

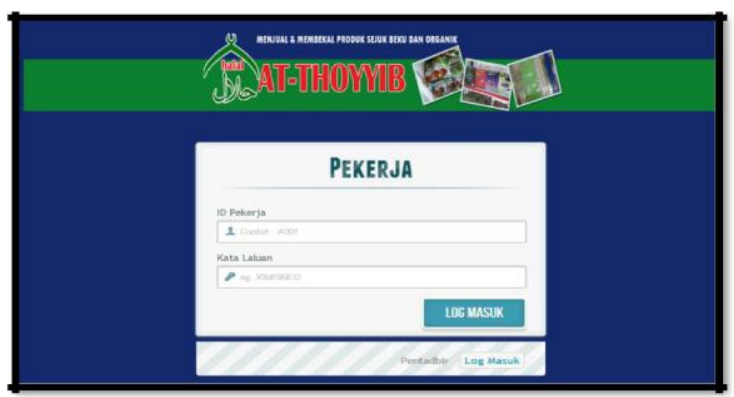

Figure 6: Main Page

On the add providers, staff, and administrators have the same module. This module allows to add new provider information. Figure 7 shows the page to add a new provider. Between the necessary information on this page is dice provider name, complete address, telephone number and email address as well.

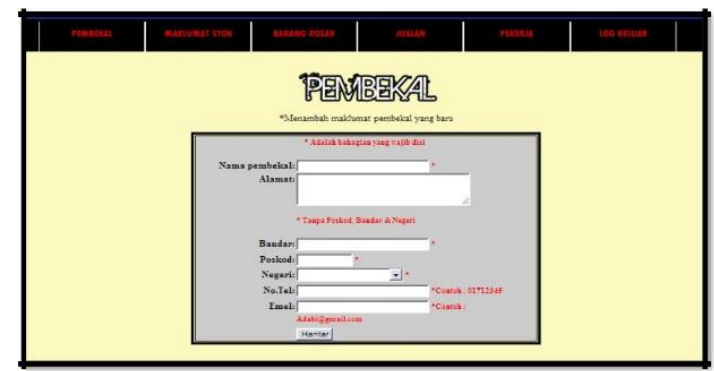


On pages update provider information workers and administrators each have the same module. This module allows any changes to provider information updated. Figure 8 show the pages update provider. Among the information that can be updated provider name, complete address, telephone number and email address as well.

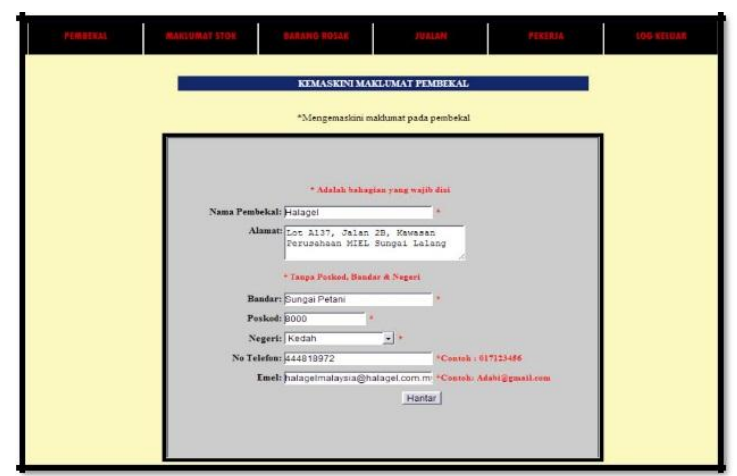

Figure 8: Update Provider

On the Add employees, the only administrators authorized to add new workers. This module allows to add new employee information. Figure 9 shows the page adding new workers. Between the necessary information on this page is complete id, employee name, date of birth, phone number, address, city, State, zip code and password. The purpose of a password is to allow employees to log into the system.

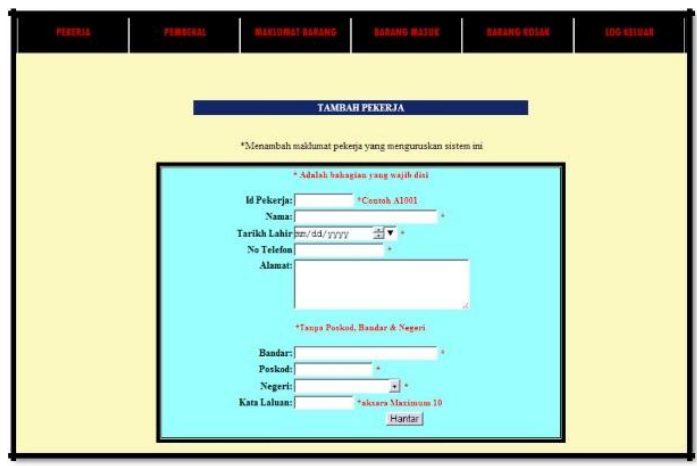

Figure 9: Page Adding Workers

On pages update employees, administrators and workers can update employee information. This module allows to update employee information. Figure 10 show a page to update employee information. Among the information that can be updated employee id, employee name, date of birth, phone number, address, city, zip code, State and also the password.

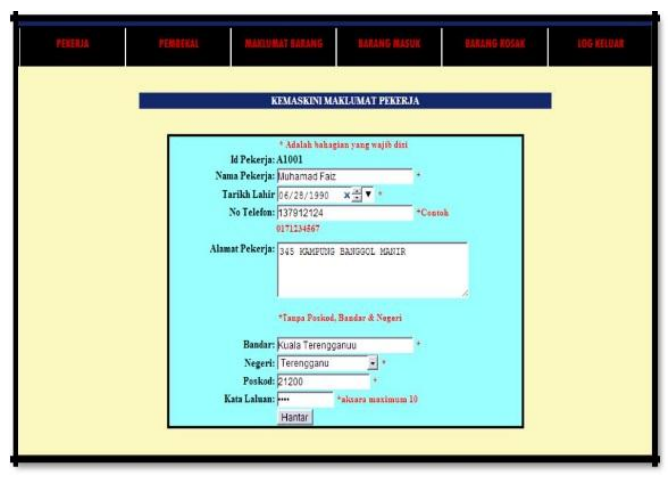

Figure 10: Update Employee

Testing the functionality of the system is performed to ensure that the data stored is the data correct, to prove the effectiveness of the system developed. The module carried out in testing this system is module functionality such as the add provider, update, delete, provider information, add items, update items, delete items, add the information in items, add items damaged, sale, add employees, update employees, leave application and also report. Table 5 shows the testing form, together with the results obtained from the testing that has been done.

Table 5: Testing Form

\begin{tabular}{|c|c|c|}
\hline Module Testing & Expected Yield & Pass/Fail \\
\hline 1. Add provider name New & $\begin{array}{l}\text { a. Users are able adding } \\
\text { information new provider }\end{array}$ & Pass \\
\hline $\begin{array}{l}\text { 2. } \quad \text { Update information } \\
\text { Supplier }\end{array}$ & $\begin{array}{l}\text { a. Users are able update } \\
\text { information supplier }\end{array}$ & Pass \\
\hline 3. Add New Items & $\begin{array}{l}\text { a. Users are able add new } \\
\text { items }\end{array}$ & Pass \\
\hline 4. Add stock items come in & $\begin{array}{l}\text { a. Users are able add stock } \\
\text { items come in }\end{array}$ & Pass \\
\hline 5. Add goods damaged & $\begin{array}{l}\text { a. The user can adding } \\
\text { information damaged goods } \\
\text { if there are items damaged }\end{array}$ & Pass \\
\hline Sales Module & $\begin{array}{l}\text { a. Users can add sales goods } \\
\text { as goods get out }\end{array}$ & Pass \\
\hline $\begin{array}{l}7 . \quad \text { Update Information } \\
\text { employee }\end{array}$ & $\begin{array}{l}\text { a. Users can update } \\
\text { information employee }\end{array}$ & Pass \\
\hline $\begin{array}{l}\text { 8. Leave application by } \\
\text { employee }\end{array}$ & $\begin{array}{l}\text { a. The user i.e. employees } \\
\text { be able to make leave } \\
\text { application via fill out the } \\
\text { form in the leave } \\
\text { application module }\end{array}$ & Pass \\
\hline $\begin{array}{l}\text { 9. Approval of leave } \\
\text { application }\end{array}$ & $\begin{array}{l}\text { a. User that is an } \\
\text { administrator approve } \\
\text { leave application }\end{array}$ & Pass \\
\hline $\begin{array}{ll}\text { 10. } & \text { Generated reports } \\
\text { i. } & \text { Goods stock report } \\
\text { ii. } & \text { Report item in } \\
\text { iii. } & \text { Report damage goods }\end{array}$ & $\begin{array}{l}\text { a. The system can generate } \\
\text { report }\end{array}$ & Pass \\
\hline 11. Search Function Goods & $\begin{array}{l}\text { a. The system can be display } \\
\text { information item in search } \\
\text { by employees or an } \\
\text { administrator }\end{array}$ & Pass \\
\hline
\end{tabular}

\section{CONCLUSION}

In conclusion, the system of inventory management Shop At-Thoyyib has successfully developed and unable to achieve the goals and objectives as set out in the early stages. This system helps administrators find out information items from time to time. Development of the system was developed to simplify the process of managing inventories by employees and administrators can be implemented easily and quickly.

\section{REFERENCE}

[1] Creswell, J.W. 2005. Educational Research. Kajian Literature.

[2] Kendall, K.E, Kendall, J.E. 2002. System Analysis and Design. 5th Edition. New Jersey: Prentice-Hall.

[3] Dewan Bahasa dan Pustaka. 2005. Kamus Dewan Edisi Empat, Kuala Lumpur.

[4] Deris, S., Samsuri, P., Jawai, D.N.A., Idris, M.Y., Mohamed R. 2002. Kejuruteraan Perisian. Malaysia: Mc Graw Hill.

[5]Definisi Inventori, dicapai pada Oktober 18,2012 dari http://pts.com.my/modules.php?name $=$ News\&file=print $\&$ sid $=56$

[6] UITM. 2012. Laman sesawang Sistem Inventori Unit Sistem Maklumat Bersepadu UiTM Terengganu, dicapai pada Oktober 19, dari http://terengganu1.uitm.edu.my/inventori/index.php

[7] Md Taib, M.F. 2011. UTHM. Tesis Sistem Aplikasi Inventori Industri Kecil Sederhana Bagi Syarikat Mi\&Da Enterprise.

[8] Universiti Tun Hussein Onn Malaysia. 2012. Panduan Menulis Tesis, Centre for Graduate Studies.

[9] Achor, M., Betz, F., Dovgal, A., Lopes, N., Magnusson, H., Richter, G., Seguy D., Vrana J. 2009. PHP Manual.PHP. Rujuk pada 23 ogos 2009. http://www.php.net/manual/en/.pada November 3, 2013, dari http://www.testingq.com/2012/10/waterfall-model-and-differentphases.html 